\title{
DESCRIPTIONS OF TWO NEW SPECIES OF EARTHWORM OF THE GENUS PHERETIMA KINBERG, 1867 (OLIGOCHAETA: MEGASCOLECIDAE) FROM MEKONG DELTA - VIETNAM
}

\author{
NGUYEN THANH TUNG \\ Can Tho University
}

\begin{abstract}
In this article describes two new species of earthworm (Pheretima mangophila Nguyen, sp. n. and Pheretima thaii Nguyen, sp. n.) are found in Mekong delta - Vietnam. Pheretima mangophila Nguyen, sp. n. (figure 2): First dorsal pore in 12/13. Spermathecal pores two pairs in 5/6/7. Genital papillae absent. Septa 5/6 - 7/8 thickish, 8/9 and 9/10 absent, 10/11 - 12/13 thin. Intestinal caeca, manicate. Integumentary micronephridia in front of clitellum drop of water- shaped. Pheretima thaii Nguyen, sp. $n$. (figure 3): First dorsal pore in 12/13. Spermathecal pores three pairs in 5/6/7/8. Genital papillae absent. Septa 5/6/7thickish, 8/9 and 9/10 absent, 7/8 and 10/11/12 thin. Intestinal caeca, manicate.
\end{abstract}

Keywords: Pheretima mangophila Nguyen, sp.n, Pheretima thaii Nguyen, sp.n., new species.

There have only been 16 earthworm species which were found in Mekong delta [5], when I collected earthworms in from 2007 to 2009 in Mekong Delta - Vietnam. Two new earthworms were found, the description of these new taxa is given in this paper.

Samples of two species were collected from various localities in Mekong delta - Vietnam. The earthworms were anesthetized in a $4 \%$ formalin solution. Some muscle tissues were isolated and preserved in 95\% ethanol solution for DNA extraction in the future.

Details of the taxonomic characters required for classification of these species are available from sources such as Thai (1983), Gates (1972), Blakemore (2002) [1, 3, 7]. Holotype and Paratypes are deposited at the Zoology Laboratory, Biology Department, Can Tho University.

In 1867, Kinberg established the genus Pheretima in the family Megascolecidae, after this genus was divided into several subgenera by Cognetti (1912) and Michaelsen (1928, 1934) and then changed to the genus rank by Sims and Easton (1972), rearranged further by Easton (1979) [2]. However, this classification seems to be not recognized by Vietnamese authors, by this reason, for the time being, only the genus Pheretima is used in the classification of the Vietnamese species of this group of earthworms, although, according to the classification system of Sims and Easton (1972) [6], these two new species are classified in the genus Metaphire.

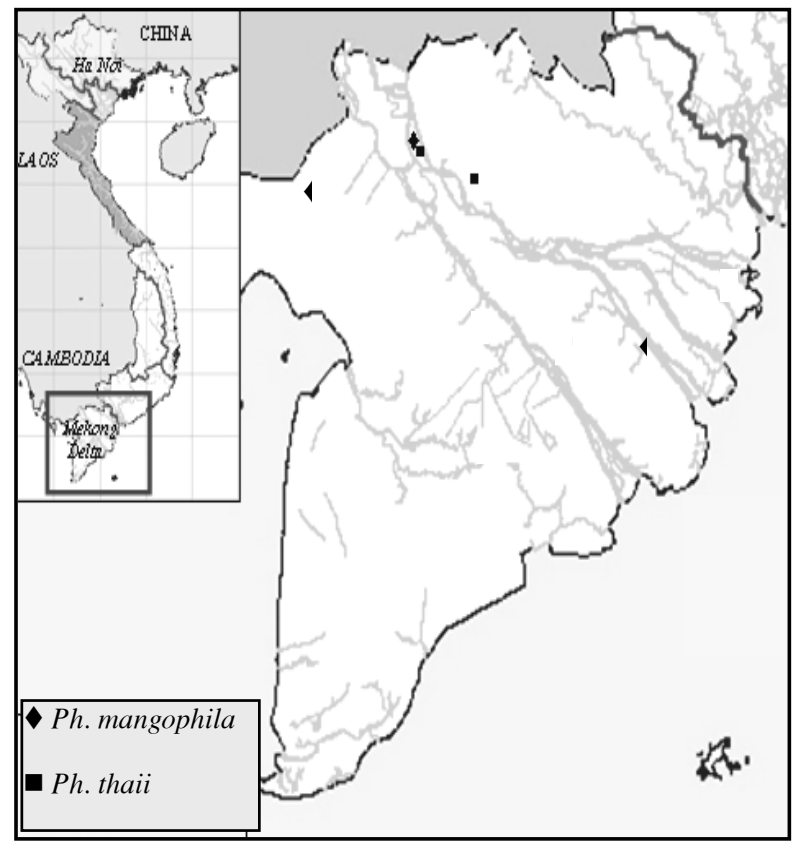

Figure 1. Collection sites of two new earthworms

Pheretima mangophila Nguyen, sp. nov. (fig. 1)

1. Material 
Holotype: Mature (clitellate) specimen, Duyen island - Cho Moi - An Giang (10³1'06.4 $\mathrm{N} ; 1^{\circ} 25^{\circ} 18.6$ E), September $5^{\text {th }} 2009$, Ho Minh Thuan, no. EWh017.

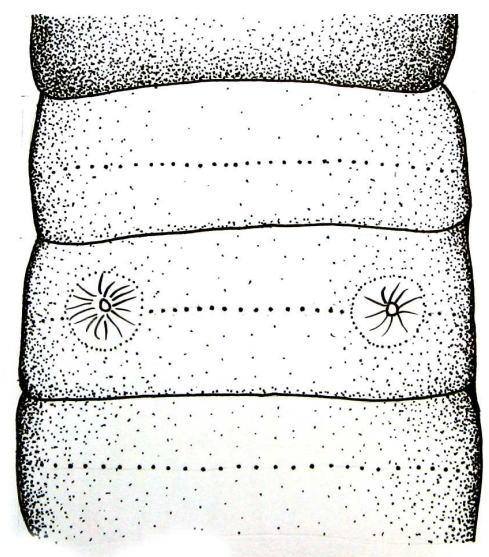

A
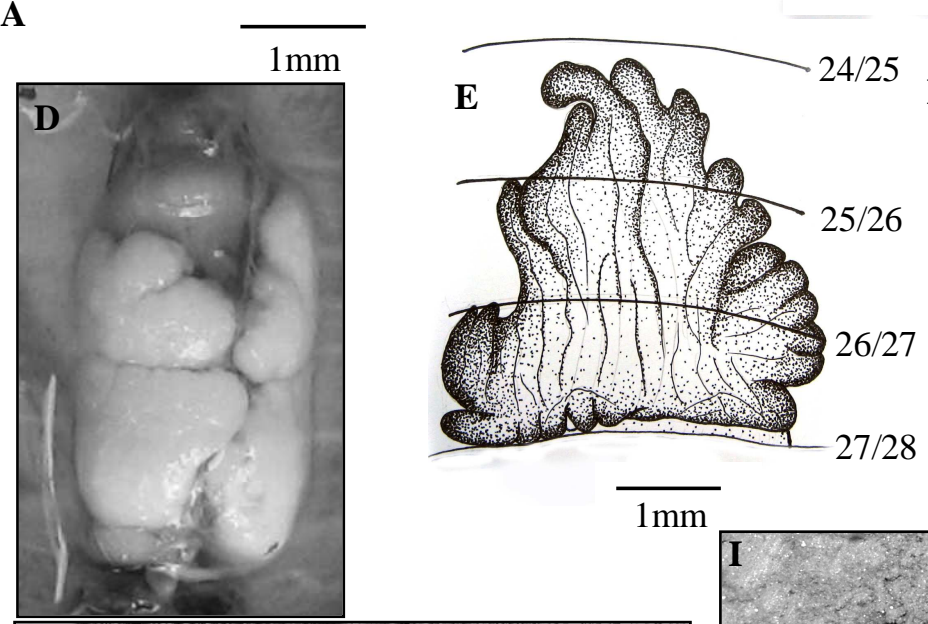

$\overline{1 \mathrm{~mm}}$
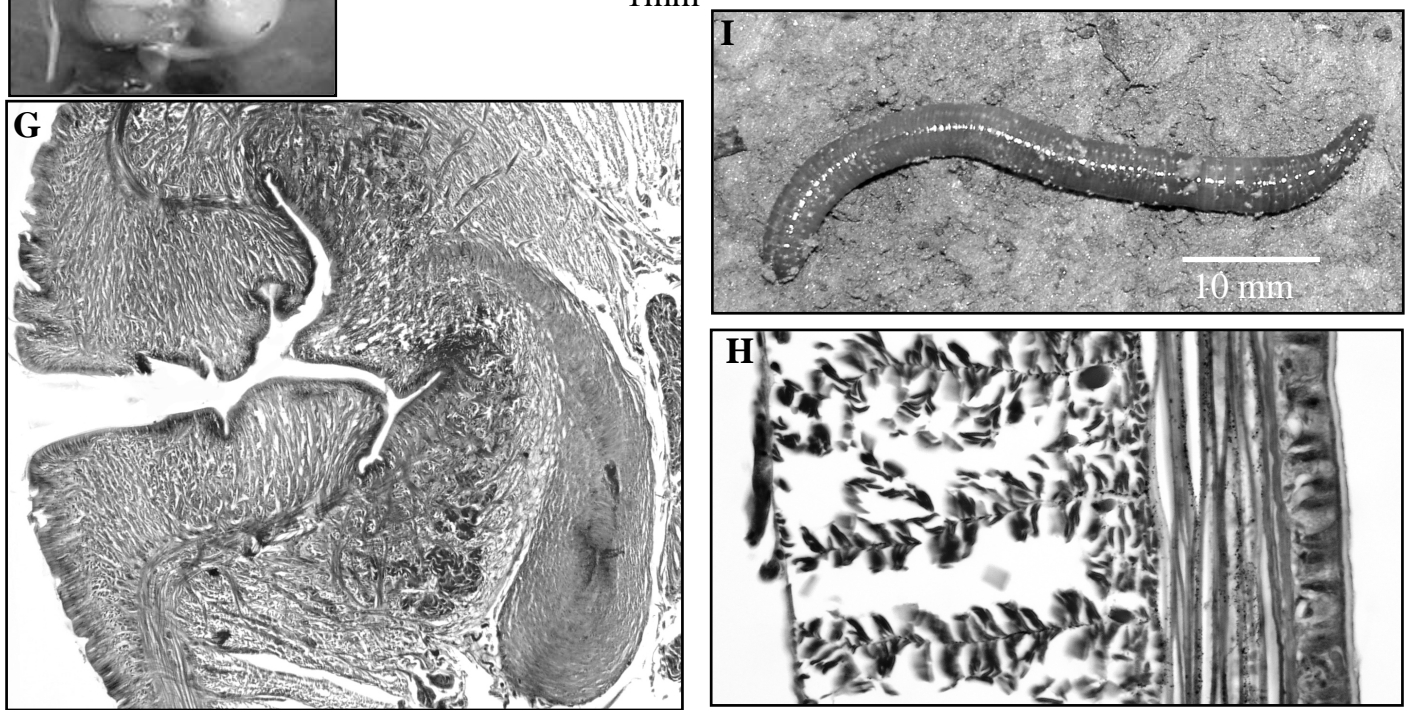

Figure 2. Pheretima mangophila Nguyen, sp. n.

A. Male pore area (mp: male pore); B. Spermathecae (amp: ampulla, dv: diverticulum); C. Prostate glands; D. Testis sacs paired; E. Intestinal caeca; F. Integumentary micronephridia drop of water-shaped;

G. Slide across on male pore area; H. Slide across on longitudinal muscle of parietes; I. Mature individual.

specimens, data as for holotype, no.EWp018EWp027; three specimens, as holotype, but August $25^{\text {th }}$ 2007, Nguyen Thanh Tung, no.EWp028-EWp030.

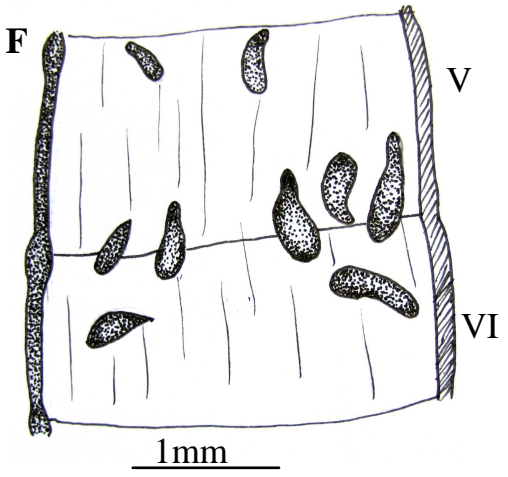

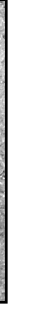




\section{Etymology}

Named after habitat mangoes garden where the species was found.

\section{Description}

External characters: Length 78 - $95 \mathrm{~mm}$, weight $0.70-1.08 \mathrm{~g}$, diameter $3.63-4.15 \mathrm{~mm}$, segment number 73 - 84; medium - size; preserved specimens black on dorsum, greyish on ventrum, and dark brown around clitellum; prostomium epilobous (1/2); first dorsal pore in 12/13; setae 57 - 70 in VIII, 49 - 51 in XXX, 14 - 20 between male pore, aa $=a b, z z=z y$; clitellum XIV - XVI, length 3.0 - $3.8 \mathrm{~mm}$, diameter $3.5-4.0 \mathrm{~mm}$, setae absent but dorsal pores present.

Spermathecal pores two pairs in 5/6/7, ventrolaterally, distance between paired spermathecal pores about 0.30 body circumference ventrally. Female pore, single, medioventrally in XIV. Male pores paired in XVIII, lateroventrally, distance between pores about 0.30 body circumference ventrally. Each in copulatory pouch with O-shaped opening, surrounded by a round swelling area with numerous transverse ridges. Genital papilla absent in both pre- and post-clitellar regions.

Internal characters: Septa 5/6 - 7/8 thickish, 8/9 and 9/10 absent, 10/11 - 12/13 thin. Gizzard round in IX - X. Intestine enlarged from XV. Intestinal caeca paired in XXVII, manicate, grey-coloured, extending to XXV. End lateral hearts in XIII. Pharyngeal micronephridia in $5 / 6$ and more than in $6 / 7$, integumentary micronephridia in front of clitellum drop of water- shaped. Lymph gland absent.

Spermathecae two pairs in 5/6/7. Ampula oval, large, yellowish. Spermathecal diverticula present, seminal chamber moniliform, sineshaped stalk, originating 1/10 distance from spermathecal pore to ampulla. Accessory gland absent in spermathecae region. Typhlosole, simply lamelliform, very small.

Testis sacs paired in X and XI, small, separated, ventral, yellowish. Seminal vesicles paired in XI and XII, very large, extending anteriorly to $\mathrm{X}$ and posteriorly to $1 / 2 \mathrm{XIII}$, white. Ovaries paired in XIII, medioventral, close to septum 12/13 and ovisacs small on 12/13 or absent. Prostate glands paired in XVIII, extending anteriorly to XVII and posteriorly to XIX or XX. Prostatic duct U-shaped. Accessory glands absent.

\section{Localities and habitats}

Pheretima mangophila sp.n. was found in Duyen Island (Cho Moi District) and Cam mountain (Chau Doc District) - An Giang Province, Chau Thanh District - Tra Vinh Province. It was only found in mangoes garden and often concentrate in places where leaves were disintegrated.

\section{Remarks}

See remarks of Pheretima thaii Nguyen, sp. nov..

Pheretima thaii Nguyen, sp. nov. (fig. 3)

\section{Material}

Holotype: Mature (clitellate) specimen, Duyen island - Cho Moi District - An Giang Province $\left(10^{0} 31^{\prime} 06.4 \mathrm{~N} ; 105^{0} 29^{\prime} 18.6 \mathrm{E}\right)$, August $25^{\text {th }} 2007$, Nguyen Thanh Tung, no. EWh031.

Paratypes (all mature specimens): $\mathrm{Six}$ specimens, data as for holotype, no. EWp032 EWp037; Two specimens, Cao Lanh - Dong

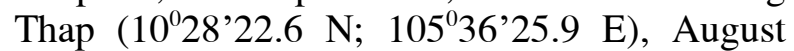
$25^{\text {th }} 2007$, Nguyen Thanh Tung, no. EWp038 EWp039; Two specimens, as holotype, but September $05^{\text {th }}$ 2009, Ho Minh Thuan, no. EWp040 - EWp041.

\section{Etymology}

The name of new species is owing to the name of Professor Dr. Sc. Thai Tran Bai who has briefed and oriented for my achievement research.

\section{Description}

External characters: Length $80-115 \mathrm{~mm}$, weight $0.93-1.07 \mathrm{~g}$, diameter $3.77-4.27 \mathrm{~mm}$, segment number 94 - 111; medium- size; preserved specimens grey, darkish on dorsum, more light on ventrum, and brown around clitellum; prostomium epilobous (1/2); first dorsal pore in 12/13; setae 54 - 60 in VIII, 69 - 71 in $\mathrm{XXX}, 13-17$ between male pore, $\mathrm{aa}=\mathrm{ab}, \mathrm{zz}$ = zy; clitellum XIV - XVI, smooth, setae and dorsal pores absent.

Spermathecal pores three pairs in 5/6/7/8, ventrolaterally, distance between paired spermathecal pores about 0.40 body 
circumference ventrally. Female pore single, medioventrally in XIV. Male pores paired in XVIII, lateroventrally, distance between pores about 0.40 body circumference ventrally. Each in copulatory pouch with large opening. Genital papilla absent in both pre- and post-clitellar regions.

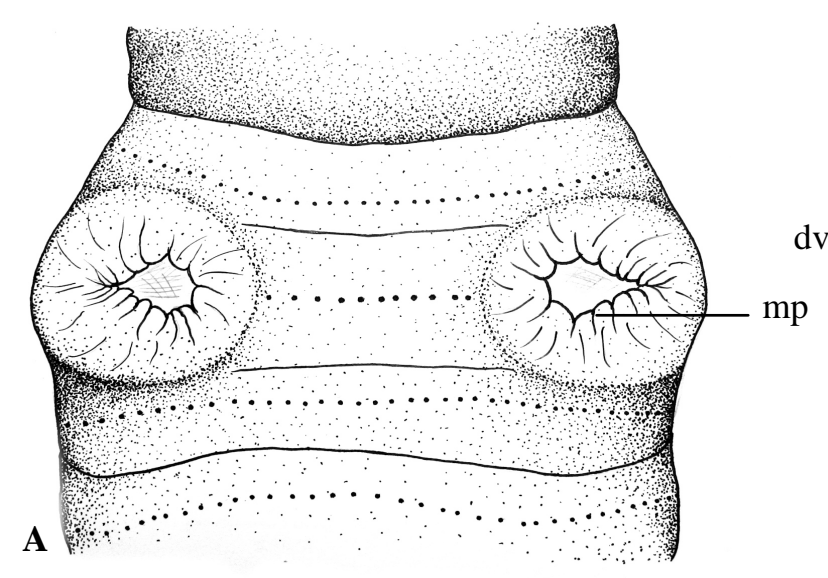

$1 \longdiv { \mathrm { mm } }$
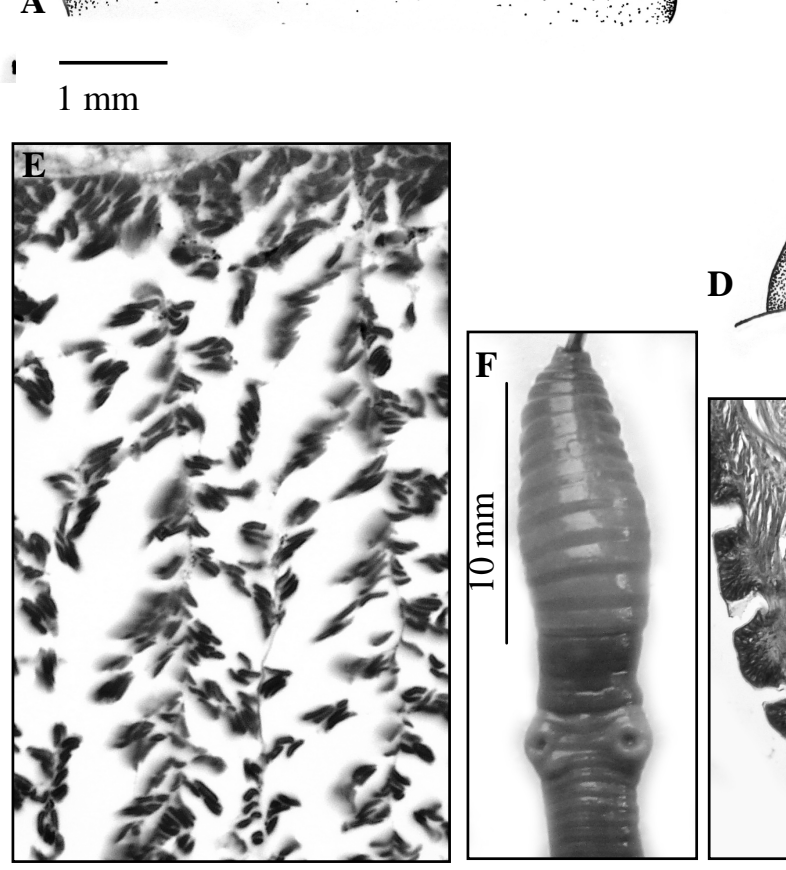

D

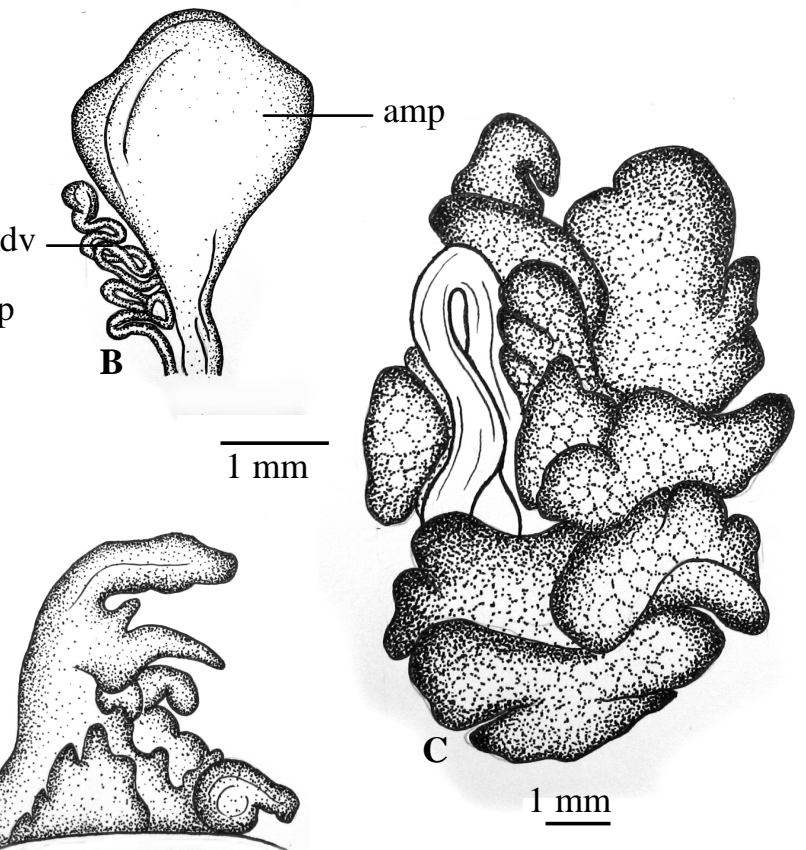

Internal characters: Septa 5/6/7 thick, 7/8 and 10/11/12 thin, 8/9/10 absent. Gizzard round in IX - X. Intestine enlarged from XV. Intestinal caeca paired in XXVII, manicate, greycoloured, extending to XXV. End lateral hearts in XIII. Pharyngeal micronephridia in 5/6/7. Lymph gland absent.

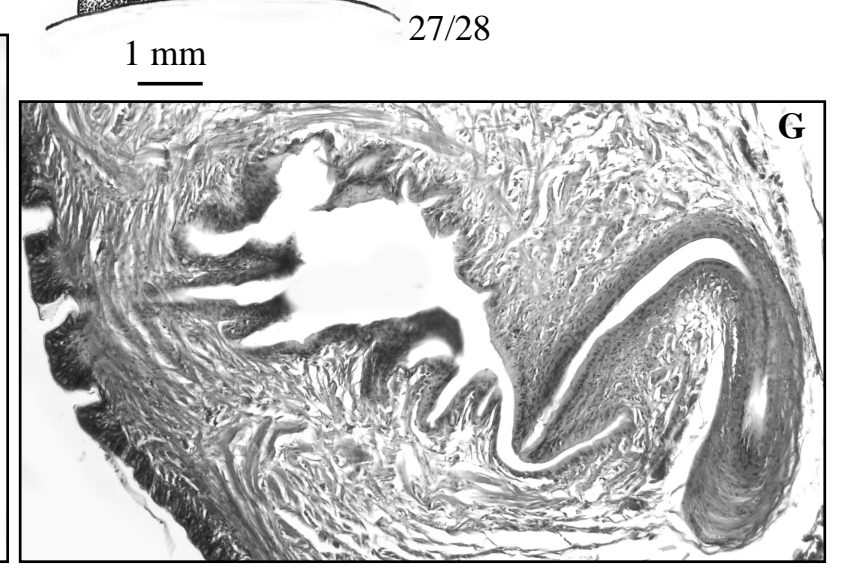

Figure 3. Pheretima thaii Nguyen, sp. n.

A. Male pore area (mp: male pore); B. Spermathecae (amp: ampulla, dv: diverticulum); C. Prostate glands; D. Intestinal caeca; E. Slide across on longitudinal muscle of parietes; F. Ventral view of clitellum and male pore region; G. Slide across on male pore area.

Spermathecae three pairs in 5/6/7/8. Ampulla oval, yellowish, surface smooth. Diverticulum from anterior face of duct in parietes, with 1 seminal chamber and a slender stalk, shorter than ampulla. Accessory gland absent in spermathecae region. Typhlosole, simply lamelliform, $\mathrm{T} \%=0.10 \pm 0.02$.

Testes paired in $\mathrm{X}$ and $\mathrm{XI}$, small, single, ventral, yellowish. Seminal vesicles paired in XI and XII, large, extending posteriorly to $1 / 2 \mathrm{XIII}$. Ovaries paired in XIII, medioventral, close to septum 12/13 and ovisacs absent. Prostate glands 
paired in XVIII, large, extending anteriorly to XVII and posteriorly to XIX . Prostatic duct large, U-shaped. Accessory glands absent.

\section{Localities and habitats}

Pheretima thaii sp. n. was collected in Duyen Island - Cho Moi district - An Giang province and Cao Lanh city - Dong Thap province and it was found in mangoes garden. Pheretima thaii often concentrate in places where leaves were disintegrated.

\section{Remarks}

Pheretima thaii sp. $\mathrm{n}$. is morphologically similar to Pheretima mangophila $\mathrm{sp}$. n. such as lymph gland absent, intestinal caeca paired manicate, first dorsal pore in $12 / 13$.... However, many taxonomic characters of Pheretima thaii Nguyen, sp. n. differ from Pheretima thaii sp. n. Besides, morphological male pores area, end lateral hearts, location of testis sacs, seminal vesicles and ovaries paired, prostomium... of two new species similar to Pheretima houlleti but they also have many different taxonomic characteristics (see table).

Table

Morphological differences between Pheretima mangophila sp. n. and Pheretima thaii sp. n. and Pheretima houlleti Perrier, 1872

\begin{tabular}{|l|c|c|c|}
\hline \multicolumn{1}{|c|}{ Species } & Ph. thaii sp.n. & $\begin{array}{c}\text { Ph. mangophila } \\
\text { sp. } \mathrm{n} .\end{array}$ & $\begin{array}{c}\text { Ph. houlleti } \text { Perrier, } \\
1872\end{array}$ \\
\hline Length & $80-115 \mathrm{~mm}$ & $78-95 \mathrm{~mm}$ & $94-120 \mathrm{~mm}$ \\
\hline Diameter & $3.77-4.27 \mathrm{~mm}$ & $3.63-4.15 \mathrm{~mm}$ & $2.9-3.3 \mathrm{~mm}$ \\
\hline Segment number & $94-111$ & $73-84$ & $96-106$ \\
\hline Weight & $0.93-1.07 \mathrm{~g}$ & $0.70-1.08 \mathrm{~g}$ & $0.5-0.9 \mathrm{~g}$ \\
\hline Setae in VIII & $54-60$ & $57-70$ & $38-41$ \\
\hline Setae in XXX & $69-71$ & $49-51$ & $39-44$ \\
\hline Setae between male pore & $13-17$ & $14-20$ & $9-10$ \\
\hline Prostomium & Epilobous $(1 / 2)$ & Epilobous $(1 / 2)$ & Epilobous \\
\hline First dorsal pore & $12 / 13$ & $12 / 13$ & $10 / 11$ \\
\hline Genital markings & Absent & Absent & Present \\
\hline & $5 / 6 / 7$ thick, $7 / 8$ and & $5 / 6 / 7 / 8$ thickish, & $5 / 6 / 7 / 8,10 / 11 / 12$ thick, \\
Septa & $10 / 11 / 12$ thin, $8 / 9 / 10$ & $8 / 9 / 10$ absent, & $8 / 9 / 10$ absent \\
& absent & $10 / 11 / 12 / 13$ thin & \\
\hline Spermathecae & 3 paireds, in 5/6/7/8 & 2 paireds, in 5/6/7 & 3 paireds, in 6/7/8/9 \\
\hline Gizzard & IX $-\mathrm{X}$ & IX - X & IX - X \\
\hline Intestinal caeca & Manicate & Manicate & Simple \\
\hline Lymph glands & Absent & Absent & Present \\
\hline
\end{tabular}

Acknowledgenments: I am grateful to Professor Dr. Sc. Thai Tran Bai and Associate Professor Dr. Do Van Nhuong for giving me the useful suggestion on earthworm taxonomy. I also thank Ho Minh Thuan for collecting earthworm specimens.

\section{REFERENCES}

1. Blakemore R. J., 2002: Cosmopolitan Earthworms - an Eco-Taxonomic Guide to the Peregrine Species of the World: 62 237, VermEcology, PO BOX 414 Kippax, ACT 2615, Australia.
2. Easton E. G., 1979: Bull. Br. Mus. Nat. Hist. (Zool.), 35: 1-126.

3. Gates G. E., 1972: Burmese Earthworms An introduction to the systematics and biology of megadrile oligochaetes with special reference to Southeast Asia. Trans. Am. Phil. Soc., New Series, 62: 1 - 326.

4. Nakamura Y., 1999: Checklist of earthworms of Pheretima genus group (Megascolecidae: Oligochaeta) of the world, Edaphologia: 64.

5. Nguyen T. T., Tran T. A. T., 2008: Journal of Can Tho University, 10: 59-66. 
6. Sims R. W., Easton E. G., 1972: Biological Journal of the Linnean Society, 4: 169-268.

7. Thai T. B., 1983: Vietnam Earthworms
(Systematics, Fauna, Distribution and Zoogeographic), $\mathrm{PhD}$ - thesis in Biology, Moscow (In Russian translate into Vietnamese by the author).

\title{
MÔ TẢ 2 LOÀI GIUN ĐẤT MỚI \\ THUỘC GIỐNG PHERETIMA (OLIGOCHAETA: MEGASCOLECIDAE) Ở ĐỒNG BÀNG MÊ KÔNG - VIÊTT NAM
}

\section{NGUYỄN THANH TÙNG}

\begin{abstract}
TÓM TÁ́T
Bài này mô tả phân loại học 2 loài giun đất mới được tìm thấy ở Đồng Bằng Sông Cửu Long - Việt Nam.

Pheretima mangophila Nguyen, sp. nov. (hình 2): Có lỗ lưng đầu tiên ở 12/13, 2 đôi túi nhận tinh 5/6/7, 1 đôi nhú đực ở XVIII, không có nhú phụ. Vách 5/6 - 7/8 hơi dày, 8/9/10 tiêu biến, 10/11/12/13 mỏng, manh tràng hình lược ở XXVII, tuyến trứng ở 12/13, túi trứng khi xuất hiện ở 12/13. Vi thận thành phía trước đai có hình giọt nước.

Pheretima thaii Nguyen, sp. nov. (hình 3): Có lỗ lưng đầu tiên ở 12/13, 3 đôi túi nhận tinh 5/6/7/8, 1 đôi nhú đực ở XVIII, không có nhú phụ. Vách $5 / 6 / 7$ dày, $7 / 8$ và $10 / 11 / 12$ mỏng, $8 / 9 / 10$ tiêu biến, manh tràng hình lược ở XXVII, tuyến trứng ở 12/13, không có túi trứng.
\end{abstract}

Ngày nhận bài: $30-8-2010$ 